\title{
HUBUNGAN POLA ASUH ORANG TUA DI RUMAH DENGAN INTERAKSI SOSIAL TEMAN SEBAYA PADA SISWA KELAS IV DI SD NEGERI JATI O3 PAGI JAKARTA TIMUR
}

\author{
Oleh : Nur Wahyuni ${ }^{1)}$ Mimin Ninawati ${ }^{2)}$ \\ PGSD FKIP Universitas Muhammadiyah Prof.Dr.Hamka), 2)
}

\begin{abstract}
ABSTRAK
Tujuan Dalam penelitian ini adalah untuk mengetahui ada atau tidaknya hubungan antara pola asuh orangtua terhadap interaksi sosial teman sebaya pada siswa kelas IV di SDN Jati 03 Pagi Jakarta Timur. Metode yang digunakan dalam penelitian ini adalah metode korelasi. Pengambilan sampel dalam penelitian ini menggunakan teknik sampling jenuh. Hasil penelitian menunjukan bahwa hubungan pola asuh orang tua di rumah dengan interaksi sosial teman sebaya merupakan faktor yang dibutuhkan seorang anak untuk membentuk karakter atau kepribadian, sedangkan interaksi sosial teman sebaya merupakan suatu bentuk interaksi untuk mengendalikan emosinya. Hal ini menunjukkan bahwa pola asuh orang tua dirumah memberikan sumbangan sebesar 22,08\% kepada interaksi sosial teman sebaya, sedangkan $77,92 \%$ merupakan kontribusi dari faktor-faktor lain.
\end{abstract}

Kata Kunci : Hubungan Pola Asuh Orang Tua, Interaksi Sosial Teman Sebaya

\section{PENDAHULUAN}

Pendidikan adalah segala pengaruh yang diupayakan sekolah terhadap anak dan remaja yang diserahkan kepadanya agar mempunyai kemampuan yang sempurna dan kesadaran penuh terhadap hubungan - hubungan dan tugas-tugas sosial mereka. Pendidikan merupakan usaha sadar yang dilakukan pemerintah melalui kegiatan bimbingan, pengajaran, atau latihan yang berlangsung disekolah dan diluar sekolah sepanjang hayat, untuk mempersiapkan peserta didik agar dapat memainkan peranan dalam berbagai lingkungan hidup secara tepat dimasa yang akan datang.

Menurut Tridhonanto (2014), Pola asuh pada orang tua ada tiga macam yaitu pola asuh Otoriter, pola asuh demokratis dan pola asuh permisif. Tanpa disadari, orang tua merupakan salah satu dalam menerapkan pola asuh yang benar untuk anaknya. Kenyataannya orang tua masih ada yang mendikte atau menyetir anak, seharusnya orang tua menjalin komunikasi secara terbuka dan menyenangkan dengan anak namun tetap ada batasan-batasan tertentu agar anakpun terbiasa terbuka pada orang tua ketika ada hal yang ingin disampaikan atau hal-hal yang tidak di inginkannya. Berdasarkan pola asuh orang tua maka diharapkan anak dapat berinteraksi sosial dengan baik di kelas dan sekolah, khususnya berinteraksi di lingkungan sekolah.( Anggraeni, 2011) Interaksi sosial merupakan bentuk 
pelaksanaan kedudukan manusia sebagai makhluk sosial. Artinya, berbagai bentuk pergaulan sosial menjadi bukti betapa manusia membutuhkan kebersamaan dengan orang lain.

Adapun tujuan dari diadakannya penelitian ini tidak lain adalah untuk mengetahui ada atau tidaknya hubungan antara pola asuh orangtua terhadap interaksi sosial teman sebaya pada siswa kelas IV di SDN Jati 03 Pagi Jakarta Timur.

\section{METODE PENELITIAN}

Populasi yang digunakan dalam penelitian ini adalah adalah siswa kelas 4 SDN Jati 03 Pagi Jakarta Timur berjumlah 34 siswa. Teknik pengambilan sampel siswa menggunakan teknik sampling jenuh di mana semua anggota populasi menjadi sampel.

Variabel penelitian ini adalah hubungan pola asuh orang tua sebagai variabel bebas dengan intereaksi sosial teman sebaya sebagai variabel terikat.

Metode pengumpulan data ini dengan menggunakan Sumber data yang diambil dalam penelitian ini berasal dari sampel yang diambil satu kelas sebanyak 30 siswa. Berupa skor yang diperoleh dari angket. Data pola asuh orang tua dan interaksi sosial teman sebaya diambil dari skor angket..

\section{HASIL DAN PEMBAHASAN}

Penelitian ini dilakukan pada siswa kelas 4 di SDN Jati 03 Pagi Jakarta timur pada bulan januari sampai bulan juni 2017 semester genap tahun ajaran 2016/2017.

\section{Data pola asuh orang tua di rumah}

Perolehan dari Interval kelas yang didapat dari penyebaran angket yang telah dilakukan didapat hasil angket Pola Asuh Orang Tua Dirumah di SDN Jati 03 Pagi, sebagian besar siswa banyak memperoleh skor angket yaitu antara 77-81, yaitu sebanyak 11 orang atau sebesar 32,36\%, dan siswa yang memperoleh skor angket tertinggi antara 87-91 yaitu sebanyak 3 siswa atau sebesar 8,82\% sedangkan siswa yang memperoleh skor angket terendah antara 62-66 yaitu sebanyak 5 orang atau sebesar $14,705 \%$.

\section{Data Interaksi Tmena Sebaya}

Peroleh dari Interval kelas yang didapat dari penyebaran angket Interaksi Sosial Teman Sebaya didapat hasil yang terlihat sebagian besar siswa memperoleh skor angket yaitu antara 74-78, yaitu sebanyak 10 orang atau sebesar 29,4 \% , dan siswa yang memperoleh skor angket tertinggi antara 89-93 yaitu sebanyak 3 orang atau sebesar 8,82 \% sedangkan siswa yang 
memperoleh skor angket terendah antara 64-68 yaitu sebanyak 4 orang atau sebesar $11,8 \%$.

Dari hasi pengujian di atas selanjutnya dilakukan perhitungan pengujian korelasi antara Pola Asuh Orang Tua Dirumah dengan Interaksi Sosial Teman Sebaya sebesar 0,469981 pada taraf siginifikan $5 \%$ dan $\mathrm{dk}$ 34, diperoleh Ltabel $=0,349$, karena thitung lebih besar dari ttabel (thitung = $0,469981>$ ttabel $=0,349)$ maka Ho ditolak dan $\mathrm{H} 1$ diterima.

Lalu selanjutnya dilakukan perhitungan Uji-t diperoleh thitung = $2,98163>$ ttabel $=2,042$, pada taraf siginifikan $0,05 \mathrm{dan} \mathrm{dk}=34-2=32$ terlihat bahwa hasil yang diperoleh thitung lebih besar dari ttabel. Karena thitung $=2,98163>$ ttabel 2,042, maka simpulan yang bisa didapat adalah terdapat hubungan yang signifikan antara Pola Asuh Orang Tua Dirumah dengan Interaksi Sosial Teman Sebaya pada siswa kelas IV SDN Jati 03 Pagi, Jakarta Timur.

Selanjutnya untk mengetahui seberapa besar persentase hubungan antara pola asuh hubungan pola asuh orang tua dirumah dengan interaksi sosial teman sebaya, dilakukan perhitungan koefisien determinasi $\left(\mathrm{r}^{2}\right)$. Dari perhitungan tersebut didapat koefisien determinasi sebesar 22,08 \%. Jadi
Pola Asuh Orang Tua Dirumah memberikan sumbangan sebesar 22,08\% terhadap Interaksi Sosial Teman Sebaya pada siswa kelas IV SDN Jati 03 Pagi, Jakarta Timur. Sedangkan 77,92\% merupakan kontribusi dari faktor-faktor lain seperti lingkungan tempat tinggal, lingkungan sekolah, pengaruh budaya, dan pengaruh perubahan zaman.

Orang tua dapat memberikan pola asuh yang benar untuk anaknya sehingga anak bisa menirukan apa saja yang dilakukan oleh orang tuanya dalam kegiatan sehari - hari, baik itu perkataan maupun perbuatan. Orang tua yang baik akan menghasilkan anak yang baik, begitupun sebaliknya orang tua yang tidak baik akan mengasilkan anak yang tidak baik juga. Karena orang tua merupakan dasar pertama dalam pembentukan pribadi anak.

Sebagai data pendukung demi menunjang data penelitian sesuai dengan hasil pertanyaan peneliti yang diajukan kepada guru kelas yang bersangkutan, hasil yang guru paparkan mengenai pola asuh orang tua itu sendiri adalah bahwa pola asuh orang tua memegang perananan penting dalam membentuk karakter anak. Karena apa yang dipelajari anak tentang pendidikan dari orang tuanya baik itu perkataan maupun perbuatan akan diterapkan dalam interaksi 
terhadap teman sebaya. Anak yang suka dibentak oleh orang tua akan membentak teman. Anak merasa hal itu biasa saja karena orang tuanya sering melakukan. Dengan interaksi teman sebaya anak akan belajar mengelola emosi. Pengelolaan emosi yang baik akan menempatkan posisi anak yang baik dalam wilayah interaksi dengan teman sebaya. Interaksi teman sebaya ini sangat menentukan pembentukan perilaku anak. Anak salah memilih teman dalam bergaul maka anak akan semakin terbawa dengan kenakalan teman-teman sebayanya. Dengan demikian, setelah diajukan uji hipotesis, penelitian ini didapatkan hasil "Terdapat Hubungan Pola Asuh Orang Tua Dirumah Dengan Interaksi Sosial Teman Sebaya Pada Siswa Kelas IV Di SDN Jati 03 Pagi, Jakarta Timur".

\section{SIMPULAN}

Berdasarkan hasil penelitian dapat disimpulkan bahwa pola asuh orang tua dirumah merupakan faktor yang dibutuhkan seorang anak untuk membentuk karakter atau kepribadian, sedangkan interaksi sosial teman sebaya merupakan suatu bentuk interaksi untuk mengendalikan emosinya. Berdasarkan uji signifikasi koefisien diperoleh nilai $t_{\text {hitung }}=2,98163$ dengan $t_{\text {tabel }}$ $=>2,042$ yang berarti $\mathrm{H}_{0}$ di tolak dan $\mathrm{H}_{1}$ diterima. Dan dengan nilai nilai koefisien korelasi rhitung $=0,469981$. Kemudian nilai koefisien determinasi yang diperoleh dari hasil perhitungan adalah $\mathrm{r} 2=22,08 \%$. Hal ini menunjukkan bahwa pola asuh orang tua dirumah memberikan sumbangan sebesar 22,08\% kepada interaksi sosial teman sebaya, sedangkan $77,92 \%$ merupakan kontribusi dari faktor-faktor lain seperti lingkungan tempat tinggal yaitu rumah yang berkaitan dengan pola asuh orang tua, lingkungan sekolah, pengaruh kebudayaan, dan lain-lain.

\section{DAFTAR PUSTAKA}

Anggraeni, D.K. (2011). Pola Asuh Orang Tua dan Kemandirian Remaja. Jurnal Trisula volume IV.

Tridhonanto, A. \& Beranda Agency. (2014). Mengembangkan Pola Asuh Demokratis. Jakarta: PT. Elex Media Komputindo. 